cemoti $\begin{aligned} & \text { Cahiers d'études sur la Méditerranée } \\ & \text { orientale et le monde turco-iranien }\end{aligned}$

$7 \mid 1989$

Le clientélisme de parti en Europe du sud

\title{
Le clientélisme de parti et la science politique turque
}

Semih VANER

\section{(2) OpenEdition \\ Journals}

Édition électronique

URL : http://journals.openedition.org/cemoti/462

DOI : $10.4000 /$ cemoti.462

ISSN : $1777-5396$

Éditeur

AFEMOTI

\section{Édition imprimée}

Date de publication : 1 janvier 1989

Pagination :

45-55

ISSN : 0764-9878

Référence électronique

Semih VANER, "Le clientélisme de parti et la science politique turque », Cahiers d'études sur la Méditerranée orientale et le monde turco-iranien [En ligne], 7| 1989, mis en ligne le 30 mars 2004, consulté le 08 septembre 2020. URL : http://journals.openedition.org/cemoti/462 ; DOI : https:// doi.org/10.4000/cemoti.462

Ce document a été généré automatiquement le 8 septembre 2020

Tous droits réservés 


\title{
Le clientélisme de parti et la science politique turque
}

\author{
Semih VANER
}

\section{RÉSUMÉS}

Le concept de clientélisme attire peu les chercheurs en sciences sociales qui travaillent sur la Turquie. Or l'utilisation de ce concept paraît fort utile pour l'appréhension de la réalité politique turque, notamment depuis l'accession au pouvoir de l'ANAP, en 1983. 